\title{
Matrix Production Systems - Requirements and Influences on Logistics Planning for Decentralized Production Structures
}

\author{
Niels Schmidtke \\ Fraunhofer Institute for Factory \\ Operation and Automation IFF, \\ Magdeburg, Germany \\ niels.schmidtke@iff.fraunhofer.de
}

\author{
Alina Rettmann \\ Fraunhofer Institute for Factory \\ Operation and Automation IFF, \\ Magdeburg, Germany \\ alina.rettmann@iff.fraunhofer.de
}

\author{
Fabian Behrendt \\ Magdeburg-Stendal University of \\ Applied Science, Germany \\ fabian.behrendt@h2.de
}

\begin{abstract}
In the context of the digital transformation of industry and within the framework of Industrie 4.0 and Factory Planning 4.0, new production-organizational principles with decentralized, modular and freely linked production cells are increasingly being discussed. The principle of matrix production with categorized and standardized workstations offers an extremely versatile production environment. It can be used to meet the challenge of an increasing number of product variants in variable quantities. This concept is predominantly considered from a theoretical point of view. Therefore, many aspects regarding the planning and operation of such systems are still up to debate. With the focus on logistics processes, this paper describes the requirements for such flexible, dynamic routing and self-organizing resources in material supply. Furthermore, they are investigated in a generic, conceptual model for a matrix production. Based on a reference scenario from the automotive industry, classical parameters from logistics and production organization are taken up. The influences with regard to decentralized material supply concepts and structural differences to flow production are shown by the results of simulation experiments with the generic model.
\end{abstract}

\section{Matrix production systems - An exam- ple for Industrie 4.0}

Industrie 4.0 presents the fourth industrial revolution, which is characterized as a profound change in the field of industrial production through the indentation of the digitalization and networking [1], [2] compared to the previous development stages (mechanization, mass production, automation). The networking includes production resources (machines, facilities, operating equipment, planning, IT, and control systems), as well as the human being (via technical aids). In combination with digitalization and the automation of sensor-based production resources, it is made possible to create a real-time capable, self-organizing value-adding network that is operating company-wide. The development and integration of new technologies is dissolving increasingly rigid corporate structures and control architectures. The given vision ranges from decentralized networks of modular conveyor and warehouse technology to the use of artificial intelligence for smart services in logistics [3]. The resulting increased flexibility and versatility with regard to adjustments (malfunctions, ad hoc production, and material supply adjustments) can be used to proactively give instructions or (automatically) implement measures. Order deviations can thus be controlled without significant production losses, so that there are as far as possible no deviations in terms of quantity, target date, quality, and costs [4]. Due to volatile markets and special customer requirements, there is also an increasing need to produce small batch sizes in an economically viable manner. The challenge is to produce an increasing number of variants and models of a product in variable quantities [5] up to batch size 1 .

This is where the concept of matrix production or matrix-structured production comes into play, which is characterized by a very flexible and versatile production that is linked together throughout the entire value-added chain [6].

The core element of this novel production-organizational principle are categorized, standardized, and freely interconnected production cells. These cells can be arranged in a scalable number on a production layout. The classic principle of flow production is replaced by a flexible workshop production, and the production process is carried out on production cells, which can each perform various process steps in a highly variable manner. The production cells are not interlinked by a rigid conveyor system. The transportation of the products and materials is mainly carried out by driverless transport systems (AGV) or autonomous mobile robots (AMR) [7]. Logistics processes and manufacturing are decoupled from one 
another in matrix production. With this concept, the production system with variable parts logistics is always able to switch flexibly to other cells at peak times [5]. Concerning the aspect of flexibility, this results in three new aspects in matrix production [8]:

- Executing process steps can be very different due to the individuality of the products (no fixed cycle)

- Production cells offer a varying portfolio of process steps depending on the equipment

- Process steps are not subject to any fixed constraint of a predetermined sequence due to the abolition of flow manufacturing (depending on product-specific restrictions).

On the other hand, this dynamic results in an increased coordination effort of the individual system elements with each other. Overall, the sum of possible individual decisions places higher demands on the control level or the (self-organizing) control system (e.g. the individual, networked autonomous mobile robots (AMR)). Table 1 shows a comparison of the different production organizations.

Table 1. Comparison of different Production Organization [9]

\begin{tabular}{|c|c|c|c|}
\hline & $\begin{array}{l}\text { Workshop } \\
\text { production }\end{array}$ & $\begin{array}{c}\text { Matrix } \\
\text { productio }\end{array}$ & $\begin{array}{c}\text { Flow } \\
\text { production }\end{array}$ \\
\hline $\begin{array}{l}\text { Princi- } \\
\text { ple }\end{array}$ & \multicolumn{2}{|c|}{$\begin{array}{c}\text { Performance } \\
\text { principle }\end{array}$} & Flow principle \\
\hline Layout & $\begin{array}{l}\text { Spatial } \\
\text { grouping of } \\
\text { similar } \\
\text { means of } \\
\text { production }\end{array}$ & $\begin{array}{l}\text { Production } \\
\text { cells with } \\
\text { product-ne } \\
\text { tral equip- } \\
\text { ment and } \\
\text { product-sp } \\
\text { cific base } \\
\text { functionali }\end{array}$ & $\begin{array}{l}\text { Object-re- } \\
\text { lated group- } \\
\text { ing of pro- } \\
\text { duction re- } \\
\text { sources ac- } \\
\text { cording to } \\
\text { temporal op- } \\
\text { erations se- } \\
\text { quence }\end{array}$ \\
\hline $\begin{array}{l}\text { Material } \\
\text { flow }\end{array}$ & $\begin{array}{l}\text { Undirected } \\
\text { material } \\
\text { flow }\end{array}$ & $\begin{array}{l}\text { Undirected } \\
\text { material } \\
\text { flow (unde } \\
\text { maximum } \\
\text { self-regula- } \\
\text { tion) }\end{array}$ & $\begin{array}{l}\text { Rigid, cycled } \\
\text { material flow }\end{array}$ \\
\hline $\begin{array}{l}\text { Ad- } \\
\text { vantages }\end{array}$ & $\begin{array}{l}\text { - High } \\
\text { flexibility } \\
\text { - Deploy- } \\
\text { ment of } \\
\text { universal } \\
\text { machines } \\
\text { - Versatile } \\
\text { deploy- } \\
\text { ment of } \\
\text { man- } \\
\text { power }\end{array}$ & $\begin{array}{l}\text { - Combine } \\
\text { use of re- } \\
\text { sources } \\
\text { - Shorter } \\
\text { transport } \\
\text { distances } \\
\text { in compa } \\
\text { ison to } \\
\text { worksho } \\
\text { productic } \\
\text { - Short in- } \\
\text { termediat } \\
\text { storage }\end{array}$ & $\begin{array}{l}\text { - Short } \\
\text { throughput } \\
\text { times } \\
\text { - Low } \\
\text { transport } \\
\text { distances } \\
\text { - Synchro- } \\
\text { nized de- } \\
\text { composi- } \\
\text { tion of the } \\
\text { operations }\end{array}$ \\
\hline
\end{tabular}

\begin{tabular}{|c|c|c|c|}
\hline & & & $\begin{array}{l}\text { - Clarity of } \\
\text { the produc- } \\
\text { tion pro- } \\
\text { cess } \\
\text { - Short inter- } \\
\text { mediate } \\
\text { storage }\end{array}$ \\
\hline $\begin{array}{l}\text { Disad- } \\
\text { vantages }\end{array}$ & $\begin{array}{l}\text { - High } \\
\text { space } \\
\text { consump- } \\
\text { tion } \\
\text { - Long } \\
\text { transport } \\
\text { routes } \\
\text { - More dif- } \\
\text { ficult } \\
\text { overview } \\
\text { and con- } \\
\text { trol }\end{array}$ & $\begin{array}{l}\text { - High capi- } \\
\text { tal require- } \\
\text { ments } \\
\text { - Increased } \\
\text { coordina- } \\
\text { tion and } \\
\text { control ex- } \\
\text { penditure } \\
\text { - Might lead } \\
\text { to higher } \\
\text { consump- } \\
\text { tion of } \\
\text { space than } \\
\text { other pro- } \\
\text { duction or- } \\
\text { ganizations }\end{array}$ & $\begin{array}{l}\text { - Higher } \\
\text { suscepti- } \\
\text { bility to } \\
\text { faults (e.g. } \\
\text { when rail- } \\
\text { bound) } \\
\text { - High trans- } \\
\text { formation } \\
\text { costs (for } \\
\text { production } \\
\text { changes) } \\
\text { - High capi- } \\
\text { tal require- } \\
\text { ments }\end{array}$ \\
\hline
\end{tabular}

A decisive advantage of the versatile solution advertised in matrix-structured production systems should be the ability to automatically adapt to changing product types. This can be useful to meet the challenges of volatile markets and the increasing individualization requirements of customers. In comparison to flow production, cycle times are dissolved, i.e. the period of time within components or production materials are assembled in a workstation before the work is continued on the same product at a downstream workstation. Meanwhile shorter transport distances are predicted due to the possibility of combined resource utilization (for operating materials as well as production equipment).

In this paper, the focus of modelling and simulation is on the development of a matrix-structured production system. Using the example of automobile assembly (interior, exterior) this system primarily examines the provisioning and supply processes taking place in logistics.

\section{Literature Review and related work}

In the theory and in practice, prototypical implementations (models, testbeds) have already been used to discuss and research different forms of matrix production or even modular production systems. However, only a few relevant studies have been carried out in the context of such production systems in corresponding literature databases (Science Direct, IEEE, etc.). The analysis and evaluation were mostly limited to the performance of the production process (machine utilization, product processing time). Logistics were only considered at a subordinate level. Barely any AMR working hours for material provision as well as product allocation to the corresponding production cells were examined. To evaluate the overall 
potential of the value creation system, these criteria should be taken into account.

In general, the need for versatile production concepts to meet the dynamic requirements of industrial production and development was looked at from different perspectives [11], [12], e.g. through decentralized controlled supply by several cyber-physical system entities (which are represented by autonomous software agents). In the recent past, a few research papers dealing with matrix production as a concept of cycle-independent flow production were published [6], [13]. Potentials are investigated which allow the production of different product variants without waiting times by eliminating a uniform synchronous cycle time during assembly. At this point, matrix production promises not only maximum capacity utilization but also the decoupling of humans (as logistics service providers) from the machine cycle (production). The core idea is to spatially decouple production (industrial robots) and logistics (flow of goods: production parts, tools) and reconnect them using mobile robotics (AGVs) and by networking all production participants. This topic has been taken up in [14], [15] and a comparison of a matrix-structured layout with a classic line production has been carried out. In a simulation approach, the advantages of a high system utilization with simultaneous production of several product types with unknown requirements are shown. However, the simulation models developed do not take into account the work cycles of means of transport and material supply logistics.

In [16], it is shown with the help of a simulation model, that AGVs produce a higher output then the compared systems. However, all systems being compared have a rather low utilization of the production system (between $44 \%$ and $54 \%$ ). The results of the simulation lead into a very similar direction later on.

In the context of the simulation paradigms, suitable approaches for the representation of modular production systems are [8] examined, whereby the process-oriented view is compared with the agent-based view on a qualitative level. The control logic of matrix-structured systems is formulated as an essential open research question, which in practical use requires a close interlocking between the real system, the simulation model, and other planning systems. A contribution to this question is [17], which proposes a flexibility oriented self-control as a method for machine allocation in such freely linked assembly systems. The approach aims at using the freedom of decision from the assembly priority chart for an improved system utilization [17].

Logistics processes and work cycles of autonomous operating resources are not considered here. In cooperation with the chair of the authors, the operational delivery process of matrix production is described in [18] using a mathematical model, including extended and real-time optimization under routing, allocation and planning aspects. Heuristics are used to find the best possible solution. At this point, this research focuses on the mathematical description including time frames, capacities, energy consumption, and emissions for a matrix production system with purely deterministic parameters.

Concerning prototypical implementations, the following practical examples should be mentioned:

- Kuka AG - Smart Production Center: Categorized, standardized production cells with product-neutral equipment and product-specific basic functionalities; production is decoupled from intralogistics (tool and material supply) by AGVs [5]

- Bosch Rexroth AG - Factory of the Future: Modular design of assembly lines, restructuring of the production line for new purposes using mobile machines (i.e. reconfiguration through new spatial arrangement) [19]

- Arculus GmbH - Modular Production Systems: Characteristics as independent production islands with AIsupported software and autonomous mobile robot platforms using the example of automobile production [20]

In summary, it can be seen that different forms of matrix-structured production systems are possible and must be considered differently depending on the application. In the following, the model conception including the process, object, and system properties of the present example is described.

\section{Model conception - Description of the Use-Case}

For the description of the present example, we want to conceptually derive the reference model of an implemented matrix production. First, in Section 3.1 we outline the basic production process and subdivide it into individual stationary process steps. Section 3.2 describes which kind of flow objects and mobile resources move through our system. Finally, section 3.3 describes the system structure of our model.

\subsection{Processes}

The design of the production process was preceded by the objective that the theoretical advantages of a matrix production compared to established production-organizational concepts can be verified in a model. Based on this, three main requirements for the design of the production process were defined:

(1) The process must allow degrees of freedom about process execution. It can be assumed that a matrix production can only use its advantages over other concepts if the sequence of process steps is partially variable.

(2) The process shall reflect a certain variety of variants of the production program. Due to the demand for different variants, with simultaneous fluctuations in the availability of the required shoring components, the possibility of flexible process execution is becoming more relevant. 
(3) The process times shall be realistic and comparable with established production concepts. This is the only way to ensure that the results can be compared later on.

Against this background, we decided to use the final assembly stage in the automotive industry as a model for process design, since all three requirements apply to it: The technological sequence of final assembly allows degrees of freedom in process execution. Due to a large number of customer-specific configuration options, especially for interior equipment, final assembly processes in the automotive industry are naturally characterized by a very high number of variants. The target process times are known, as these are subject to a fixed cycle time, which is largely standardized in the industry.

\subsection{Flow Objects and mobile Resources}

Table 2 contains all flow objects that run through the system. The flow objects are divided into main products and assembly materials. In our system, we consider three different vehicle types, which require model-specific assembly components (body parts, floor paneling) on the one hand, and model-independent, but equipment-specific assembly components (on-board electronics, interior) on the other. Seats are classified according to vehicle type (A, B, C) as well as according to equipment (fabric/leather).

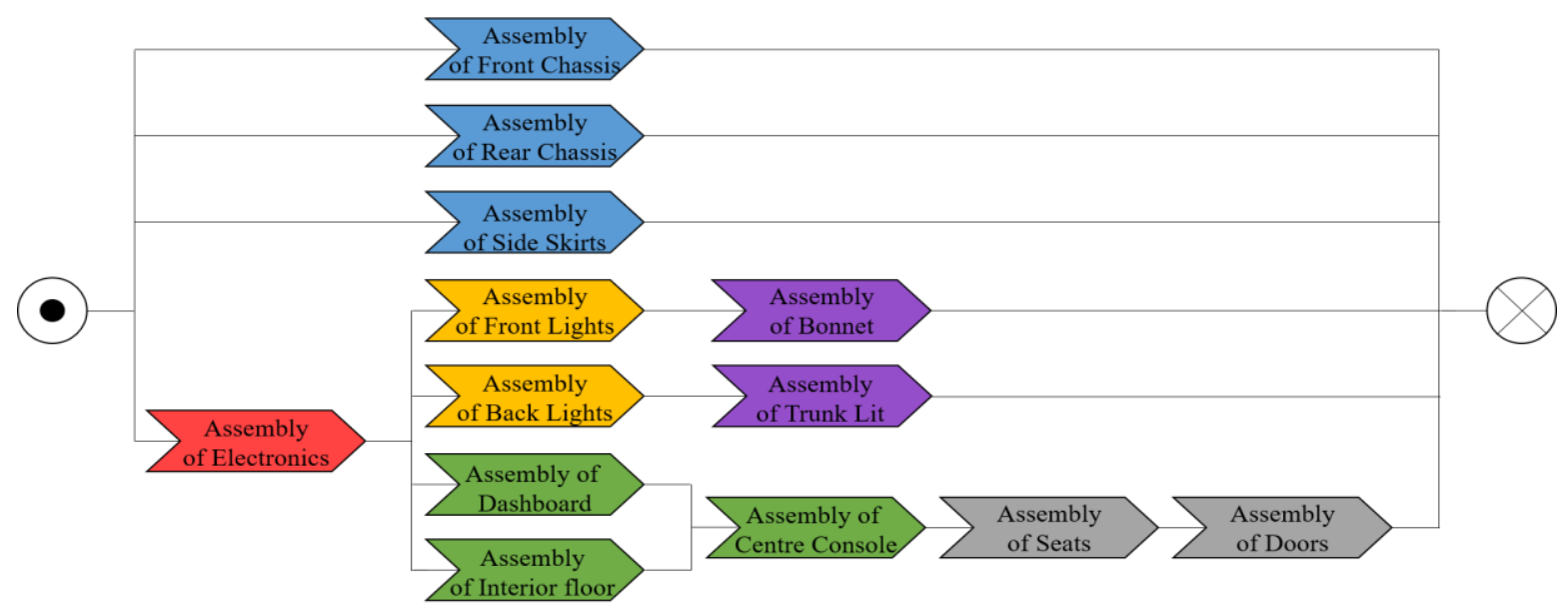

Figure 1. Process model for interior and exterior assembly in the automotive industry

The process flow outlined in Figure 1 was developed based on expert interviews with production planners of a German automotive OEM. The processes focus on the assembly of interior and exterior components and comprise 13 activities. Degrees of freedom in the process control exist especially for the body assembly (blue activities). They also concern the assembly tasks that follow directly after the electronics installation (yellow and green activities). Due to the standard cycle time in the industry, a uniform target process time is assumed for all assembly tasks, which is subject to stochastic fluctuations. Deviations from the target time also exist in cycle-controlled flow assembly systems. Current assembly processes are then terminated either during the cycle change or in the subsequent cycle. We assume that all process times are subject to a normal distribution with an expected value of 180-time units and a standard deviation of 30-time units.
Table 2. Classification of the flow objects considered in the reference model

\begin{tabular}{|c|c|c|c|c|}
\hline & \multicolumn{3}{|c|}{ PRODUCTS } \\
\hline & & Vehicle A & Vehicle B & Vehicle C \\
\hline \multirow{13}{*}{ 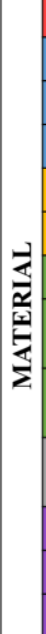 } & Electronics & \multicolumn{3}{|c|}{ Basic, Performance, Premium } \\
\hline & Front Chassis & A & B & $\mathrm{C}$ \\
\hline & Rear Chassis & A & B & $\mathrm{C}$ \\
\hline & Side Skirts & A & B & $\mathrm{C}$ \\
\hline & Front Lights & A & B & $\mathrm{C}$ \\
\hline & Back Lights & A & B & $\mathrm{C}$ \\
\hline & Interior Floor & A & B & $\mathrm{C}$ \\
\hline & \begin{tabular}{|l} 
Interior \\
Dashboard \\
\end{tabular} & \multicolumn{3}{|c|}{ Basic, Performance, Premium } \\
\hline & $\begin{array}{l}\text { Interior Centre } \\
\text { Console }\end{array}$ & \multicolumn{3}{|c|}{ Basic, Performance, Premium\} } \\
\hline & Seats & $\begin{array}{c}\text { A \{Fabric, } \\
\text { Leather) }\end{array}$ & $\begin{array}{l}\text { B \{Fabric, } \\
\text { Leather) }\end{array}$ & $\begin{array}{l}\text { C \{ Fabric, } \\
\text { Leather) }\end{array}$ \\
\hline & Bonnet & A & B & $\mathrm{C}$ \\
\hline & Trunk Lit & A & B & $\mathrm{C}$ \\
\hline & Doors & A & B & $\mathrm{C}$ \\
\hline
\end{tabular}


We assume that the demand for vehicle types and equipment variants is subject to categorical distributions. The demand distribution of the different equipment variants is product-specific. Table 3 breaks down the demand for the various product and equipment lines.

\subsection{System Description}

The system structure shown in Figure 2 is essentially derived from the process model discussed in Section 3.1. In our model, a separate workstation is provided for each

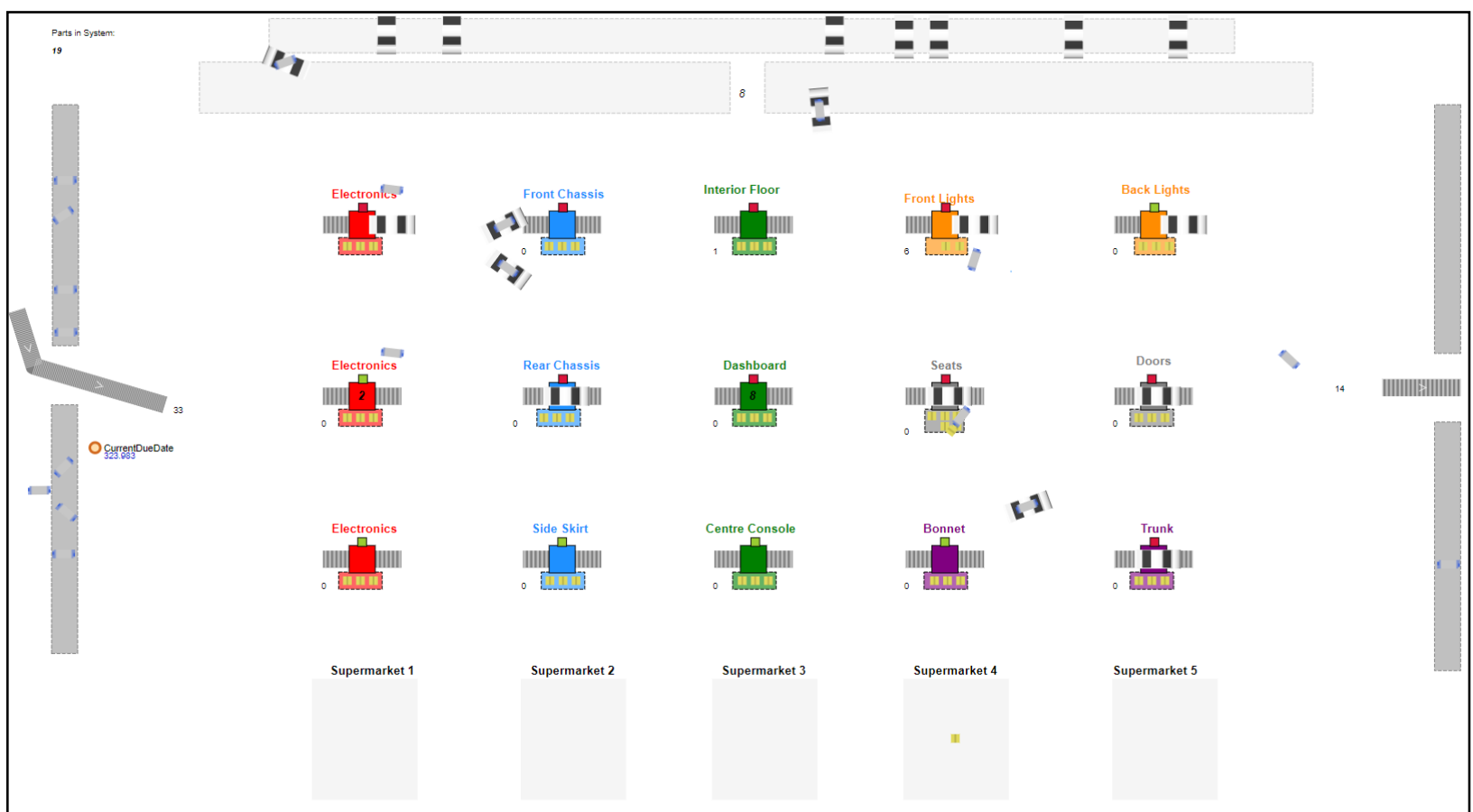

Figure 2. System structure of matrix production (Screenshot form the simulation model, created with the simulation software "AnyLogic")

The transport of products and assembly components is realized by a user-variable number of autonomous mobile robots (AMR), which move freely through matrix production. We assume that each AMR can transport all types of products and assembly components. All AMRs move through the system at a constant speed of one meter per second. Acceleration and braking times are neglected. The loading and unloading time of an AMR are constantly 60-time units, both for the provision of the car bodies and for the materials to be assembled.

Table 3. Demand for the various Product and Equipment Lines

\begin{tabular}{|l|l|l|l|}
\cline { 2 - 4 } \multicolumn{1}{c|}{} & \multicolumn{1}{c|}{$\begin{array}{c}\text { Vehicle } \\
\mathrm{A}\end{array}$} & $\begin{array}{c}\text { Vehicle } \\
\mathrm{B}\end{array}$ & $\begin{array}{c}\text { Vehicle } \\
\mathrm{C}\end{array}$ \\
\hline Product Mix & $40 \%$ & $35 \%$ & $25 \%$ \\
\hline $\begin{array}{l}\text { Interior Mix (Basic, } \\
\begin{array}{l}\text { Performance, Pre- } \\
\text { mium) }\end{array}\end{array}$ & $\begin{array}{l}\{60 \%, \\
30 \%, \\
10 \%\}\end{array}$ & $\begin{array}{l}\{50 \%, \\
10 \%,\end{array}$ & $\begin{array}{l}\{20 \%, \\
40 \%\}\end{array}$ \\
\hline $\begin{array}{l}\text { Seat Mix } \\
\text { (Fabric, Leather) }\end{array}$ & $\begin{array}{l}\{80 \%, \\
20 \%\}\end{array}$ & $\begin{array}{l}\{50 \%, \\
50 \%\}\end{array}$ & $\begin{array}{l}\{10 \%, \\
90 \%\}\end{array}$ \\
\hline
\end{tabular}

assembly task. An exception is the on-board electronics with three workstations. Since $75 \%$ of all other assembly tasks require the complete installation of the electronics, this is classified as a potential bottleneck risk. Each workstation has a processing capacity of one vehicle due to the available space. In addition, each station has an input and output buffer, which are also dimensioned with a capacity of one vehicle each.

Most of the assembly material is stored in the supermarket. Each type of material is assigned to a fixed storage position, which is located as close as possible to the assembly station in demand. It is assumed that the supermarket always stores sufficient material to meet the demand of all stations. The buffer capacity for assembly components at the workstations, if needed, is specified as seven units. This allows the influence of material supply to be considered without taking up too much space. As soon as the material is missing at the workstations, it is reordered and delivered by AMR in batches of 5 units.

The system also has a waiting area. In this area, the flow objects, which cannot directly reach their destination station yet, are stored. The transfer of the flow objects (car bodies) is carried out at the workstations via AMR to the appropriate conveyor belts while adhering to the defined loading and unloading times, so that the AMR is available for further transport tasks after this process (see 
Figure 2). For the most part, a continuous marriage of the AMR with the products is also possible at this point. From the point of view of simplified model control and to avoid the binding of resources, a transfer process to the individual workstations via conveyor belt has been implemented first.

\section{Scenario Selection and Evaluation}

Various scenarios are considered in the context of the present modelling and simulation. The simulation was done using the software "AnyLogic". The scenarios examined are presented in Table 4.

Table 4. Considered Scenarios

\begin{tabular}{|c|c|c|}
\hline & $\begin{array}{c}\text { "station } \\
\text { buffer" } \\
\text { (workstations } \\
\text { with buffer) }\end{array}$ & $\begin{array}{c}\text { "supermarket" } \\
\text { (no buffer at the } \\
\text { workstations) }\end{array}$ \\
\hline $\begin{array}{l}\text { Without } \\
\text { station } \\
\text { downtime }\end{array}$ & Scenario 1.1 & Scenario 2.1 \\
\hline $\begin{array}{l}\text { With short } \\
\text { station } \\
\text { downtime }\end{array}$ & $\begin{array}{c}\text { Scenario } 1.2 \\
\text { (downtime } 90 \\
\text { time units) }\end{array}$ & $\begin{array}{c}\text { Scenario } 2.2 \\
\text { (downtime } 90 \\
\text { time units) } \\
\end{array}$ \\
\hline $\begin{array}{l}\text { With long } \\
\text { station } \\
\text { downtime }\end{array}$ & $\begin{array}{c}\text { Scenario } 1.3 \\
\text { (downtime } 300 \\
\text { time units) }\end{array}$ & $\begin{array}{c}\text { Scenario } 2.3 \\
\text { (downtime } 300 \\
\text { time units) }\end{array}$ \\
\hline $\begin{array}{l}\text { Number of } \\
\text { parts to be } \\
\text { manufac- } \\
\text { tured }\end{array}$ & & 00 \\
\hline $\begin{array}{l}\text { Duration } \\
\text { of a } \\
\text { simulation } \\
\text { run }\end{array}$ & Open e & (flexible) \\
\hline $\begin{array}{l}\text { Size of the } \\
\text { material } \\
\text { buffer at } \\
\text { stations }\end{array}$ & 7 flow objects & No buffer \\
\hline $\begin{array}{l}\text { Quantity of } \\
\text { parts per } \\
\text { delivery }\end{array}$ & 7 flow objects & $\begin{array}{c}1 \text { flow object per } \\
\text { drive to work- } \\
\text { station }\end{array}$ \\
\hline $\begin{array}{l}\text { Size of } \\
\text { waiting } \\
\text { area }\end{array}$ & \multicolumn{2}{|c|}{25 flow objects } \\
\hline $\begin{array}{l}\text { Amount of } \\
\text { AMR in } \\
\text { the system }\end{array}$ & \multicolumn{2}{|c|}{$\begin{array}{l}\text { Corresponds to the number of flow } \\
\text { objects in the system }\end{array}$} \\
\hline
\end{tabular}

The scenarios differ with regard to the concept of material supply. In scenario 1.x, the material (which will be part of the final product) is delivered to the workstations and seven pieces of material in each class are buffered at each workstation (each workstation has its own material buffer). This means that up to 21 or 42 pieces of material ("Seats" station) are stored per workstation. In scenario 2.x, after the flow object (product $=$ car body) has been picked up, the AMR (loaded with the flow object) drives to the supermarket to collect the material, which is required for the next process step. Then the AMR (loaded with the flow object and the material) drives to the workstation at which the next processing step is carried out. During this step there is no buffer for material at the workstations, as it will be picked up directly from the supermarket for the process to come. The scenario 2.x was chosen as an opposite to scenario 1.x, since it has buffers at the workstations, but 2.x does not. An extra delivery of material in addition to the delivery of the flow object does not seem promising, as it would occupy two AMRs per delivery. Considering the fixed number of AMRs this could delay the flow of material or flow objects or even block the whole system. Therefore the object flow and the material flow were united on one AMR in the scenario 2.x.

The scenarios can also be differentiated according to the downtime (failure) of a workstation. The duration of the failure corresponds to either 90 time units (three times the processing time on one station) (scenario x.2) or 300 time units (ten times the processing time on one station) (scenario x.3). The choice of the workstation to be failed falls on the "Front Lights" workstation, so that two further processing steps are directly influenced by the delays (see Figure 1).

The following comments can be made about the simulation in general: The number of parts to be produced is set at 1,000 , so that the simulation time is approximately 10,000 time units (= about 1 week). The simulation experiments are carried out ten times each. The number of flow objects in the system ranges from 15 to 25 . 15 flow objects are selected as the lower boundary because there are 15 workstations in the system. Its average lead time is close to the theoretically calculated value of 115 time units. As can be seen in Figure 3, the lead time increases with more flow objects in the system with a continuous development. The lead time of most scenarios (except 2.1 and 2.2) is about twice as high as the theoretically minimum possible lead time. Since these values suggest that the system works inefficient, the number of flow objects in the system was limited to 25 .

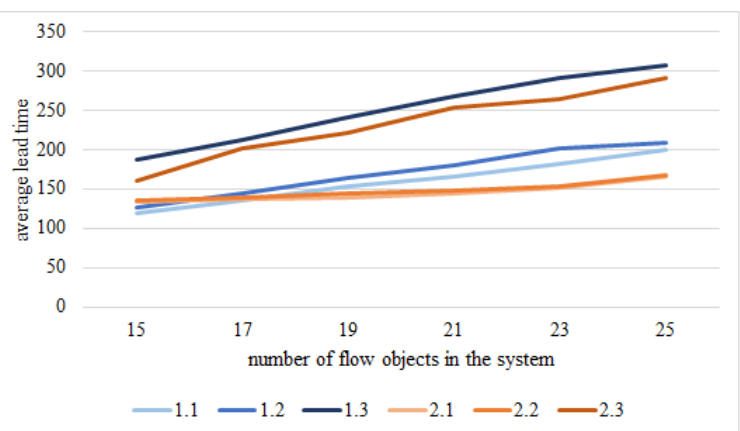

Figure 3. Average lead time per flow object 
As seen in Figure 4, the average lead time per flow object increases in all scenarios, the more flow objects are in the system at the same time. Since each workstation carries out only one processing step, the downtime of a workstation affects the overall system and can lead to a jam of flow objects. This can also be seen in the average number of flow objects in the waiting area (see Figure 4).

The strongest increase of the average lead time per flow object is visible in the scenarios 1.3 and 2.3. It has to be noted, that the graphs for these scenarios also start at a higher point. This seems reasonable, as in the x. 3 scenarios the downtime is higher than in the other scenarios.

The graphs of the scenarios 1.1 and 1.2 show a stronger increase than those of the scenarios 2.1 and 2.2 but a lower one than the x.3. The difference probably lies in the structure of the scenarios since in scenario 2.x the supermarket has to be visited for material collection before each workstation visit. This means, that the following object can already collect its material, while the prior object is still being processed at the workstation. This also leads to a lower formation of queues in front of the workstations (see Figure 4), as the first object is picked up to get the material in scenario $2 . x$ while it would still be in the queue in 1.x.

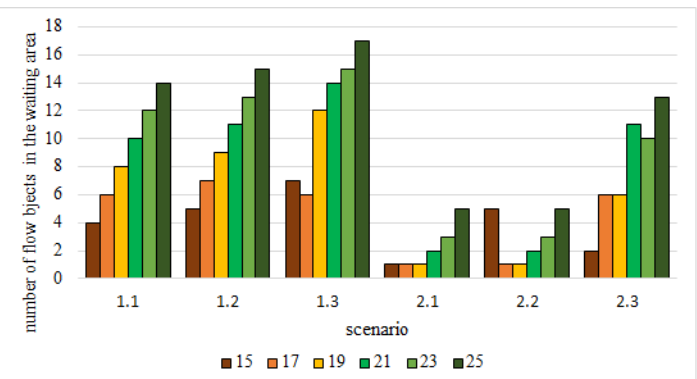

Figure 4. Average number of flow objects in the waiting area

As seen in Figure 4, the average number of pieces in the waiting line increases, if the number of flow objects in the system increases. From this perspective, a higher number of parts in the system is a clear disadvantage.

Again, the consideration can be divided into three groups: Scenario 1.3 and 2.3 form a group, Scenario 1.1 and 1.2 as well as the scenarios 2.1 and 2.2.

In general the scenarios 1.3 and 2.3 have the most flow objects in the waiting area, which can be justified with the longer downtime in this scenario. When only one workstation fails, a queue forms in front of this station.

In the scenarios 1.1 and 1.2 the average number of objects in the waiting area is significantly higher than in 2.1 and 2.2. This shows that while the overall development (e.g. the average lead time) is the same, the way the flow objects spend their time in the system seems to be very different. This might also explain why the results of the 1.x scenarios look rather alike. This conclusion seems more valid when we look at the utilization of the AMRs in Figure 5.

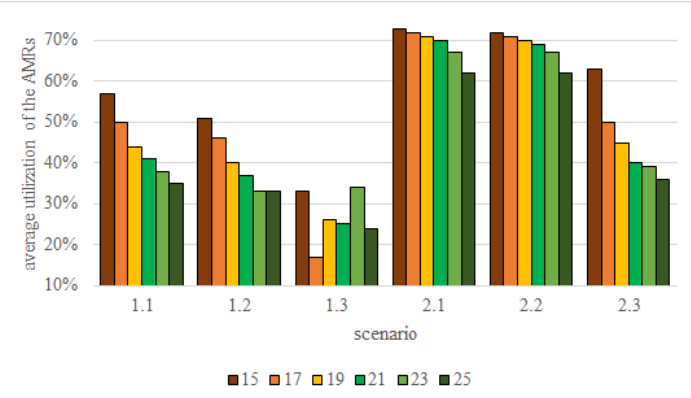

Figure 5. Average utilization of the AMRs depending on the number of objects in the system

The material transport is implemented via AMR. The number of these depends on the number of flow objects in the system. On average, the utilization of the AMR in scenarios 2.x is greater than in scenarios 1.x, since each flow object brings its own material to the workstation and therefore more transport processes to the supermarket are necessary (see Figure 5). As already stated in Figure 4, the number of flow objects in the waiting area increases with the number of flow objects in the system. This explains why the utilization of the AMR decreases with an increasing number of flow objects.

As mentioned above and seen in Figure 4, the scenarios 2.1 and 2.2 differ strongly from the other scenarios. The difference in how the flow objects spend their time in the system gets more contoured with the information from Figure 5. As the flow objects spend more time moving in the system (via AMR) and less time staying in the waiting area of the system. Therefore, the AMR utilization is higher while fewer objects are in the waiting area, compare Figure 4 and Figure 5.

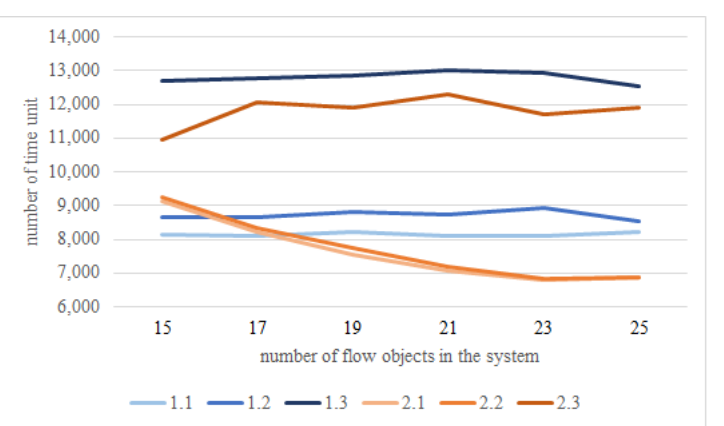

Figure 6. Average number of flow objects per scenario

It is visible in Figure 6, that the graphs can, again, be divided into three groups: Scenario 1.3 and 2.3, Scenario 1.1 and 1.2 as well as 2.1 and 2.2. 
In general scenarios 1.3 and 2.3 have the longest make span of all scenarios. This means, the long downtime of a workstation increases the make span.

The graphs of scenarios 1.1 and 1.2 both range between 8000 and 9000 time units. The graphs for the scenarios 2.1 and 2.2 start at a value of about 9000 time units. These are the only scenario graphs where the make span decreases despite the increasing number of flow objects in the system. This means that for these scenarios a higher number of flow objects is advantageous. In Figure 6 it seems that the sweet spot is around 23 flow objects in the system. With future work this value can be verified. It can be deduced that scenario $2.1(2.2)$ is more resistant to short downtimes than scenario 1.1 (1.2), in which the make span increases. However, scenario 2.3 cannot compensate for the longer failure of a workstation, since the make span increases. This development is also reflected in the average lead time, as the lead time increases at a slower rate for scenarios 2.1 and 2.2 (compare Figure 3).

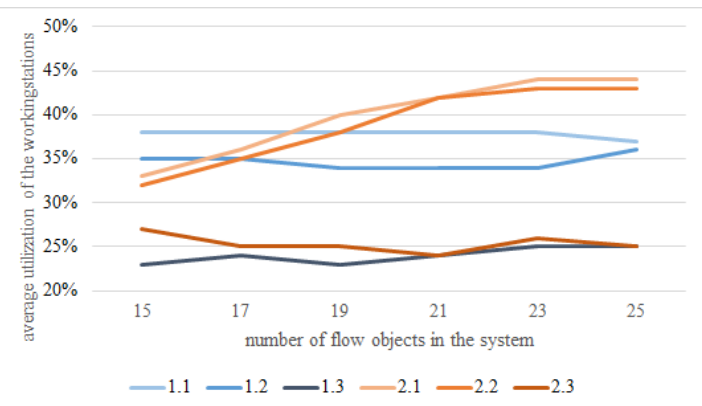

Figure 7. Average utilization of the workstations per scenario

Figure 7 looks as if Figure 6 had simply been turned upside down: It presents again the possibility to group the graphs. The graphs for the average utilization of the workstations for the scenarios 2.1 and 2.2 also begin with values less good than 1.1 and 1.2 and then rise to the highest utilizations. Scenario 2.1 reaches a higher utilization than 2.2, which can be explained with the short downtime in 2.2. The graphs for the Scenarios 1.1 and 1.2 range again quite close between $33 \%$ and $40 \%$. The lower utilization can, in parts, be explained with starvation of the workstations for material. As there is a material buffer at each station, this buffer can be empty if two flow objects of the same class (compare

Table 2) are processed directly after each other.

The utilization of the workstations is lowest in scenarios 1.3 and 2.3. Since these are the scenarios with the longest make span (see Figure 6) and the same number of flow objects are manufactured in each simulation (see Table 4), the utilization of the workstations has to be the lowest.

None of the key figures analysed so far can be cited as the reason for this low utilization of the workstations. At this point, the decoupling of logistics (cycle) and production becomes clear. There are many reasons for the current values. On the one hand, the system needs time to start up from the initial state. On the other hand, in further processing approaches (see Chapter 5), measures that can be used to optimize capacity utilization must be implemented and checked on the model side (material assembly, expansion of the functionalities of a workstation, adaptation of the control logic (forecast), for example in the sense of predictive assignment of flow objects to their workstations). This consideration shows us the limitations of the modelling shown here.

The modelling and its structure can provide at least clues and perhaps even in parts explanations for these low workstation utilization values. In each station, one process step is executed and the processing time in each station is, compared to the driving time, rather short. While each process step takes 30 time units, the average driving time takes 10 time units, $1 / 3$ of the processing time. In addition, each step takes 30 time units, meaning that the clock of the flow production is implemented. This shows that the current model is very closely, maybe even too closely, modelled to the flow production. This could be evaded in future work, if more than one process step is executed on one station or if the processing time per step is prolonged.

Only one work step can be carried out on each workstation. As a result, the system is still very much based on flow production and the downtime of a workstation has a greater impact on the lead time of the flow objects, since each workstation has to be visited (see Figure 4).

The selection of the next workstation is implemented in the modelling by specifying from four up to seven subsequent stations. The four following workstations are based on the spatial proximity (see Figure 2) and the (assembly) priority graph (see Figure 1). For example, the successor of station 5 are station 1-3, 4, 6 and 8. Station 1-3 all do the same process step of adding electronics, while station 4, 6 and 8 are direct neighbours of station 5 and can be executed directly after station 5 (compare Figure 1 and Figure 2). If all following stations have already been visited or are occupied, the flow object is referred to a general node, where the next station is determined depending on the availability of the workstations and the already finished workstations. If no selection is possible at this point, the object is moved to the waiting area of the workstation and brought to the waiting area of the system. As soon as the workstation is available, the flow object is picked up by an AMR from the waiting area and driven to the respective workstation.

This query allows more variation in the choice of the next work station than a pure flow production, and it ensures that the priority graph is adhered to and that no flow object is 'lost' in the system. However, it also limits the selection of the next workstation and is very close to the flow production. Furthermore, it can lead to many flow objects being in the waiting area (see Figure 5).

In addition, there is no direct succession of objects in the system. As soon as one object is finished, the next one 
is brought in. The flexibility of matrix production is a disadvantage here: the downstream a flow object must first be brought to its next workstation. It does not matter whether the object comes from the waiting area or another station. This travel time is missing in the occupancy statistics. The logic of the query also plays an important role. The hierarchical query, in which the completion of the processing steps is queried in a certain order, favors the formation of queues. For reasons of space, these are not attached directly to the stations, but in the northern part (see Figure 2). In future work it will be exciting to find out, how a buffer with a buffer space directly at the workstations affects the utilization.

The transition phase is part of the calculations of the key figures. At the beginning of the simulation, the system is empty and the first flow object is created. Since a flow object is generated every 30 time units, it takes a certain amount of time until the system can run under a given (full) load. This time is included in the calculation of the utilization. In relation to the total simulation time (approx. 10.000 time units), this proportion of the startup time still has a corresponding impact on the calculation of the machine utilization.

If one takes another look at the mentioned literature, more precisely [16], one can see that they also had a rather low utilization of the production system (between 44 and $54 \%$ ).

Overall, scenario 2.x is more resistant to small failures than scenario 1.x. The longer breakdown of a workstation can be seen as a stress test that both scenarios were able to overcome with scenario 2.x performing better than scenario 1.x. The make span, lead time and the number of objects in the waiting area of scenario 2.x are also smaller than that of scenario 1.x. Because of the more modular structure of scenario 2 (decoupling of material availability and station), it is also possible to use more workstations than scenario 1 . In both scenarios, the degree of utilization of the workstations is currently very low (see Figure 7). As mentioned before, the causes are diverse.

\section{Further application approaches}

Against the background of the different forms of matrix-structured production systems, the previous model work provides a model-based basis for further processing approaches. With regard to the scenario expansion, the failure of further workstations as well as a simultaneous failure of several workstations with regard to the aspects of capacity optimization and reallocation of the logistical provision processes are to be examined as the next immediate steps. At this point, further adaptable production units can be generated in the sense of Industrie 4.0 and, depending on the scenario, can be integrated adaptively. In order to expand the theoretical advantages of matrix production with regard to standardized production cells, further expert discussions are needed to implement and evaluate a sensible combination of process steps on a workstation with product-neutral assembly skills. Above all, there is the question of the technical implementation options against the background of the different use of tools and diversified material supply tasks. Another major challenge is the scalability of the solution to real production systems with a correspondingly large number of items from an OEM.

In the context of the focus on logistics, there is a consecutive task for us to improve the behavior of the AMRs with regard to utilization and route optimization. One scenario, which is currently being implemented, is the assembly of material supply tasks so that an AMR can simultaneously pick up and deliver the materials from several workstations in coordinated production lots from the supermarket. Since in its current form only 5 parts per transport are delivered to a workstation, potential improvements for the logistics transports can be expected here.

In the further course of research, there is a requirement to implement a comparable model of classic series production with the same framework parameters (same product example, process chain with $\mathrm{n}$ machines) in order to quantify the advantages and disadvantages of corresponding production organizations in appropriate key figures (utilization, lead time, service level, etc.). In comparison to previous work [14], [15] in the context of agent-based simulations, the focus should be on the transport and deployment processes. The previous simulation approaches focus on the aspect of machine utilization while producing several product types at the same time. The work cycles of means of transport and the material supply logistics are not taken into account in the evaluation.

\section{Conclusion}

As mentioned before, some general lessons can be learned from this modelling approach:

- The matrix production should not be aligned too close to the flow production. While both are a manifestation of the flow principle, they differ greatly in their rules of implementation (see Table 1). The structure of the used model is only slightly, but still too strongly, aligned to the flow production (compare Figure 7). Above all, a major lever will be the resolution of synchronized cycle times, which in the form of a matrix production are not necessary due to the decoupling of production and logistics (expected effect: increase in utilization)

- The application of the flow production manifested itself in different variants in this model. One option is the application of the clock principle, by always having the same amount of time for each process step or having the same delivery time compared to the processing time.

- The selection logic for the next station offers a level of freedom too small for a matrix production system. 
It should be adapted to the level of freedom of the matrix production system.

The price for these lessons learned are the partly low key figures, which were discussed in chapter 4.

The developed research approach forms the first basic framework for the initialization of matrix-structured production systems. Based on the example shown, initial empirical values with regard to reliability, utilization and sources of interference can be investigated; corresponding model limits are described in detail in the previous two chapters. Overall, the research contribution forms a cornerstone for further investigation with regard to the design of the individual workstation, AMRs and their parameterization. It also offers the possibility to simulate individual sub-areas from existing line or workshop production of real production systems and to compare and evaluate the use of matrix production.

From a methodological point of view, the knowledge gained is embedded in the development of a planning system approach for material supply for decentralized logistics planning, which can be given to a logistics planner as decision support. For this purpose, the previously mentioned comparison to series production (in the further comparison also to a workshop production) is being considered in order to be able to make fundamental, reliable decisions regarding the design of the production organization.

Since a matrix-structured system view also requires a certain degree of intelligence of the individual objects and stations, it is possible to control the production process via a predictive provision of materials (e.g. through the use of artificial intelligence methods, neural networks) [21]. The supply order for logistics and in particular the special requirements of Industrie 4.0 for the " 8 Right of Logistics" (the right object at the right time in the right amount at the right place etc.) [22] can be solved and implemented in this way.

\section{References}

[1] Bauernhansl, T.; ten Hompel, M.; Vogel-Heuser, B.; Industrie 4.0 in Produktion, Automatisierung und Logistik. Anwendung, Technologien, Migration. Wiesbaden: Springer Vieweg, 2014, pp. 321

[2] Reinhart, G., Handbuch Industrie 4.0 - Geschäftsmodelle, Prozesse, Technik, Carl Hanser Verlag, 2017.

[3] Behrendt, F.; Schmidtke, N.; Glistau, E., Der Intelligente Logistikraum: Neue Gestaltungsformen im Kontext der digitalen Transformation, Industrie 4.0 Management 35 (2019) 4, pp. 35-38

[4] Winkler, H.; Seebacher, G.; Oberegger, B., Effizienzbewertung und -darstellung in der Produktion im Kontext von Industrie 4.0, Obermaier, R. (Hrsg.): Industrie 4.0 als unternehmerische Gestaltungsaufgabe. Betriebswirtschaftliche, technische und rechtliche Herausforderung, Wiesbaden: Springer, 2016, pp. 219-243.

[5] KUKA AG, Matrix-Produktion: ein Beispiel für Industrie 4.0, Online: https://www.kuka.com/de-de/branchen/loesungsdatenbank/2016/10/solution-systems-matrix-produktion, Access: 26/05/2020
[6] Greschke, P.; Schönemann, M.; Thiede, S.; Herrmann, C., Matrix structures for high volumes and flexibility in production systems, Procedia CIRP 17 (2014) pp. 160-165

[7] Poll, D., Das Ende des Fließbands, Online: https://www.produktion.de/trends-innovationen/das-endedes-fliessbands-306.html, Access: 02/07/20

[8] Feldkamp, N.; Bergmann, S.; Straßburger, S., Modelling and Simulation of Modular Production Systems, 18. ASIM-Conference Simulation in Production and Logistics, 18-20/09/2019, pp. 391-401

[9] Schenk, M.; Wirth, S.; Müller, E.: Factory Planning Manual. Berlin, Heidelberg 2010

[10] Koren, Y., Shpitalni, M., Design of reconfigurable manufacturing systems, Journal of Manufacturing Systems 29 (2010), pp. 130-141.

[11] Popp, J; Wehking, K.-H.: Neuartige Produktionslogistik für eine wandelbare und flexible Automobilproduktion: Logistics Hournal: Proceedings, 2016.

[12] Bayhan, H.; Meißner, M.; Kaiser, P.; Meyer, M.; ten Hompel, M.: Presentation of novel real-time production supply concept with cyber-physical systems and efficiency validation by process status indicators: The International Journal of Advanced Manufacturing Technology, 2020.

[13] Greschke, P., Matrix-Produktion als Konzept einer taktunabhängigen Fließfertigung, TU Braunschweig, Institut für Werkzeugmaschinen und Fertigungstechnik, Dissertation, 2016.

[14] Schönemann, M.; Herrmann, C.; Greschke, P.; Thiede, S., Simulation of matrix-structured manufacturing systems, Journal of Manufacturing Systems 37 (2015) 1, pp. 104112

[15] Büth, L.; Broderius, N.; Herrmann, C.; Thiede, S., Introducing agend-based simulation of manufacturing systems to industrial discrete-event simulation tools, IEEE $15^{\text {th }} \mathrm{In}-$ ternational Conference on Industrial Informatics (INDIN), Emden, Germany, 24-26/07/2017, pp. 1141-1146

[16] Filz, M.; Gerberding, J.; Herrmann, C.; Thiede, S.: Analysing different material supply strategies in matrix-structured manufacturing systems: $52^{\text {nd }}$ CIRP Conference on Manufacturing Systems, 2019.

[17] Müller, M.; Meyer, A., Simulative Evaluation of a flexiblity-oriented, autonomous production control in freely interlinked assembly systems, ASIM-Conference Simulation in Production and Logistics, 18-20/09/2019, pp. 423-433

[18] Bányai, A.; Illés, B.; Glistau, E.; Coello Machado, N.; Tamás, P.; Manzoor, F.; Bányai, T., Smart cyber-physical manufacturing - extended and real-time optimization of logistics resources in matrix production, Applied Sciences Basel: MDPI, Vol.9.2019, 7, Article 1287

[19] Bosch Rexroth AG, Factory of the Future, Online: https://apps.boschrexroth.com/rexroth/de/factory-of-thefuture/, Access: 14/06/2020

[20] Arculus GmbH, The modular production system by Arculus, Online: https://www.arculus.de/, Access: 14/06/2020

[21] Lang, S.; Reggelin, T.; Behrendt, F.; Nahhas, A., Evolving Neural Networks to solve a tow-stage hybrid flow shop scheduling problem with family setup times, 53rd Hawaii International Conference on System Sciences, Wailea, Maui, Hawaii, USA, 2020

[22] Schmidtke, N.; Behrendt, F.; Meixner, S.; Thater, L., Technical potentials and challenges within internal logistics 4.0., IEEE (2018) 4th International Conference on Logistics Operations Management (GOL), pp. 1-10 